\title{
Reconstruction of the Black Sea Deep-Water Circulation Using INMOM and Comparison of the Results with the ARGO Buoys Data
}

\author{
E. A. Korshenko ${ }^{1, *}$, N. A. Diansky ${ }^{1,2,3}$, V. V. Fomin ${ }^{1}$ \\ ${ }^{1}$ Zubov State Oceanographic Institute, Moscow, Russian Federation \\ ${ }^{2}$ Lomonosov Moscow State University, Moscow, Russian Federation \\ ${ }^{3}$ Marchuk Institute of Numerical Mathematics, Russian Academy of Sciences, Moscow, \\ Russian Federation \\ *zhenyakorshenko@gmail.com
}

Purpose. The present paper is focused on theoretical analysis of hydrophysical characteristics of the Black Sea in 2011.

Methods and Results. The Black Sea hydrophysical characteristics are calculated using a version of the marine circulation $\sigma$-model (Institute of Numerical Mathematics Ocean Model - INMOM) for the Black, Azov and Marmara seas (BAMS) with high spatial $1 \mathrm{~km}$ resolution and $20 \sigma$-levels distributed non-uniformly over the depth. Quality of the simulated salinity and temperature fields is assessed by their comparison with the data of the ARGO deep-profiling floats available for the period under consideration. Degree of correspondence of the modeled current fields to the observed ones is estimated based on the average deep-sea current velocities calculated from the data on the Argo profiling floats' movements.

Conclusion. The comparative analysis results show that the INMOM adequately reproduced vertical distribution of the Black Sea hydrophysical characteristics. Comparison of the simulated temperature and salinity fields with those derived from the ARGO buoys data demonstrates the fact that the strongest deviations of the characteristics under study are observed in the sea upper layers $(0-100 \mathrm{~m})$; whereas in the deep-water layers $(300-1500 \mathrm{~m})$, the degree of consistency between the simulated results and the field data is much more higher. On the depths below 800 meters, the deep-sea anticyclonic flows with the velocities attaining $1.5 \mathrm{~cm} / \mathrm{s}$ are present. The revealed feature is not typical of the generally accepted scheme of the Black Sea cyclonic circulation.

Keywords: the Black Sea, numerical modeling, hydrophysical fields, ARGO profiling floats, deepwater circulation, countercurrent.

Acknowledgements: the research was carried out within the framework of scientific projects No. 1805-00353 and No. 18-35-00512 at the RFBR financial support.

For citation: Korshenko, E.A., Diansky, N.A. and Fomin, V.V., 2019. Reconstruction of the Black Sea Deep-Water Circulation Using INMOM and Comparison of the Results with the ARGO Buoys Data. Physical Oceanography, [e-journal] 26(3), pp. 202-213. doi:10.22449/1573-160X-2019-3-202-213

(C) 2019, E. A. Korshenko, N. A. Diansky, V. V. Fomin

(C) 2019, Physical Oceanography

\section{Introduction}

Since the early 40 s of the last century, scientists have been interested in studying the deep-water circulation direction of the Black Sea. G. Neumann in his work * 1942 adhered to the hypothesis on this issue, suggesting the presence of a two-layer system of currents in the Black Sea (BS). According to his hypothesis, a cyclonic direction prevails in the upper layer of this system, but the sign of the currents changes with depth, and a deep-water countercurrent occurs on the $300 \mathrm{~m}$ horizon with subsequent intensification to the $1000 \mathrm{~m}$ horizon [1].

* Neumann, G., 1942. Die absolute Topographie des physikalischen Meeresniveaus und Oberflächenströmungen des Schwarzen Meeres. Annalen der Hydrographie und Maritimen Meteorologie, 70(9), pp. 265-282. 
The problem statement concerning the BS circulation in a two-layer system of currents remains relevant until now. To solve it in the modern interpretation in [2], in contrast to G. Neumann work, the confirmation of the cyclonic circulation in the lower layer was obtained.

The disadvantages of such a problem statement are that, depending on the chosen two-layer stratification parameters, different results can be obtained. According to [3], which came out almost half a century after G. Neumann hypothesis, there are no reliable climatic data for the deep-water layers below the $300 \mathrm{~m}$ horizon, allowing to draw any definite conclusions about the deep-water circulation direction. Currently, according to [1], research continues on the directivity of the BS deep-water circulation, including theoretical calculations and laboratory experiments, to substantiate the presence or absence of deep-water countercurrent [4]. The ambiguity of the solution of this problem is due to the fact that both cyclonic and anticyclonic type of the BS deep circulation do not contradict the general physical understanding of its circulation. The nature of the BS deep circulation is determined by the peculiarities of the BS density stratification distribution, when small perturbations of this stratification can lead to cyclonic or anticyclonic circulation.

In work [3] also mentions that the first attempts at numerical modeling to the BS circulation study began in the mid-70s of the last century by several groups of Soviet scientists under A. Sarkisyan [5] and G. Marchuk [6] leadership. However, even by the beginning of the 21 st century, in most of the works devoted to this field of research, the main attention is paid to the calculations of currents only in the upper BS layer, and the currents on the deep horizons are given only some assessment, if that. Nevertheless, in one of the works of those years [7], the assessment of the climatic distribution of near-bottom currents for the entire BS water area based on seawater density, wind and bottom topography data, resulted in the establishment of a predominantly anticyclonic orientation of these currents. In recent years, the possibilities of numerical modeling of the three-dimensional water dynamics have reached a completely different level, which, perhaps, was the reason for the increased interest in the direction of the BS circulation of the deep-water circulation. Currently, the most active research work in this field is being conducted by a group of scientists from Marine Hydrophysical Institute (MHI) of the Russian Academy of Sciences (see, for example, [1] and research *).

* Markova, N.V., Dymova, O.A. and Demyshev, S.G., 2016. [The Black Sea Deep-Water Circulation Research by Results of Numerical Modelling and In-Situ Data: P. I. MHI-Model Numerical Experiments]. In: MHI, 2016. Kompleksnye Issledovaniya Morey Rossii: Operativnaya Okeanografiya $i$ Ekspeditsionnye Issledovaniya: Materialy Molodezhnoy Nauchnoy Konferentsii (Sevastopol, 25-29 April) [Combined Research of the Seas of Russia: Operational Oceanography and Expeditionary Research: Materials of Youth Scientific Conference]. Sevastopol: MHI, pp. 122-127 (in Russian);

Lukyanova, A.N., Bagaev, A.V., Plastun, T.V., Markova, N.V., Zalesny, V.B. and Ivanov, V.A., 2016. The Black Sea Deep-Water Circulation Research by Results of Numerical Modelling and InSitu Data: P. II. INM RAS Model Numerical Experiment. In: MHI, 2016. Kompleksnye Issledovaniya Morey Rossii: Operativnaya Okeanografiya i Ekspeditsionnye Issledovaniya: Materialy Molodezhnoy Nauchnoy Konferentsii (Sevastopol, 25-29, April) [Combined Research of the Seas of Russia: Operational Oceanography and Expeditionary Research: Materials of Youth Scientific Conference]. Sevastopol: MHI, pp. 111-116 (in Russian). 
They believe that only results of numerical calculations supported by in-situ data can adequately describe the BS deep-sea circulation scheme and that the conclusions should always be based on the results of multi-model experiments, and not on the calculations of one model.

The core objective of the presented work is the numerical simulation of the BS hydrophysical parameters in 2011 according to a scenario similar to that described in work *, and further comparison of the results with the field data on salinity $S$ and temperature $T$ obtained by measuring ARGO profiling floats during the same year. In this way, the intercalibration of the BS circulation $\mathrm{z}$-model $* *$ and $\sigma$-model $* * *$ is carried out with a different representation of the vertical coordinate.

ARGO autonomous deep-sea profiling floats appeared as part of an international program related to the World Ocean monitoring in 1999. Their main task is to drift at a certain parking depth, to measure the vertical distribution of salinity and temperature during periodic ascent to the surface to transmit the information they received through satellite and dive back ****.

\section{The Model and ARGO Data Description}

To calculate the BS hydrophysical characteristics, the INMOM model of sea and ocean circulation $[8,9]$ is used, which belongs to the class of $\sigma$-models of the ocean [10]. The model is based on a system of primitive equations in hydrostatics and Boussinesq approximations, written horizontally in generalized spherical orthogonal coordinates and vertically - in a $\sigma$-coordinate system. To calculate the water density, the equation of state [11], specifically designed for ocean circulation models, is used. Difference approximations by spatial coordinates are built on the $C$ grid in the Arakawa classification. This model versions are successfully applied to calculate the Black Sea circulation $[8,12]$.

The INMOM model for the Black, Azov and Marmara seas (BAMS) is implemented with a spatial resolution of 0'45" in longitude and 0'32" in latitude, which corresponds to $\sim 1 \mathrm{~km}$. The grid area in the horizontal plane contains $1224 \times 800$ nodes. Vertically $20 \sigma$-levels are considered. To set the BS depth, the GEBCO Earth Topography data (http://www.gebco.net) with 30" spatial resolution is used.

* Markova, N.V., Dymova, O.A. and Demyshev, S.G., 2019. Numerical Simulations of the Black Sea Hydrophysical Fields below the Main Pycnocline: Validation by ARGO Data. In: V. Karev D. Klimov, K. Pokazeev, eds., 2018. Physical and Mathematical Modeling of Earth and Environment Processes. Springer Proceedings in Earth and Environmental Sciences. Cham: Springer, pp. 15-21. https://doi.org/10.1007/978-3-030-11533-3_2

** Demyshev, S.G. and Korotaev, G.K., 1992. Chislennaya Ehnergosbalansirovannaya Model' Baroklinnyh Techenij Okeana s Nerovnym Dnom na Setke C [Numerical Energy-Balanced Model of Baroclinic Ocean Currents with Rough Bottom on a C Grid]. In: IBM RAS, 1992. Chislennye Modeli $i$ Rezul'taty Kalibrovochnyh Raschetov Techenij v Atlanticheskom Okeane [Numerical Models and the Results of Calibration Calculations of Currents in the Atlantic Ocean]. Moscow: IBM RAS, pp. 163-231 (in Russian).

*** Diansky, N.A., 2013. Modelirovanie Cirkuljacii Okeana i Issledovanie Ego Reakcii na Korotkoperiodnye i Dolgoperiodnye Atmosfernye Vozdejstvija [Ocean Circulation Modeling and Investigation of Ocean Response to Short- and Long-period Atmospheric Forcing]. Moscow: Fizmatlit, 272 p. (in Russian).

**** Markova, N.V., Dymova, O.A. and Demyshev, S.G., 2016. [The Black Sea Deep-Water Circulation Research by Results of Numerical Modelling and In-Situ Data: P. I. MHI-Model Numerical Experiments]. In: MHI, 2016. Kompleksnye Issledovaniya Morey Rossii: Operativnaya Okeanografiya i Ekspeditsionnye Issledovaniya: Materialy Molodezhnoy Nauchnoy Konferentsii (Sevastopol, 25-29 April) [Combined Research of the Seas of Russia: Operational Oceanography and Expeditionary Research: Materials of Youth Scientific Conference]. Sevastopol: MHI, pp. 122-127 (in Russian). 
The high-resolution initial data is smoothed several times with a Tukey filter, then interpolated to the model grid and limited to $3 \mathrm{~m}$ depth near the coast. It's aimed for the function describing the undisturbed depth of the sea to be non-zero and have sufficient smoothness, which is a necessary condition for $\sigma$-models [8].

To construct the initial conditions for temperature and salinity, threedimensional mean monthly climatic fields of the Black [13], Azov * and Marmara $* *$ seas are used. All necessary data is interpolated to the grid area of the model.

Parameterization of large-scale horizontal turbulent diffusion for temperature and salinity is carried out applying a 2-order operator with $100 \mathrm{~m}^{2} / \mathrm{s}$ coefficient. A 4-order operator with $0.007 \cdot 10^{9} \mathrm{~m}^{4} / \mathrm{s}$ coefficient is used as the lateral viscosity. The vertical viscosity and diffusion coefficients are selected according to the Philander - Pacanowski parameterization [14]. The vertical viscosity coefficient varies from $10^{-4}$ to $5 \cdot 10^{-3} \mathrm{~m}^{2} / \mathrm{s}$, and the diffusion one - from $10^{-7}$ to $5 \cdot 10^{-3} \mathrm{~m}^{2} / \mathrm{s}$ for $T$ and $S$. For the parametrization of the mixing induced by wind waves in the near-surface $3 \mathrm{~m}$ sea layer, the diffusion and viscosity coefficients are set equal to $5 \cdot 10^{-3} \mathrm{~m}^{2} / \mathrm{s}$. For temperature and salinity at the lateral boundaries and the bottom, zero-fluxes condition is set, for the speed at the boundaries the impermeability condition, supplemented by the free-slip conditions at the lateral boundaries and quadratic friction at the bottom [8, 12].

Atmospheric action (including turbulent heat and moisture flows, short- and long-wave radiation and precipitation) is determined according to the calculation of SKIRON atmospheric model (http://forecast.uoa.gr) with a spatial resolution of $\sim 10 \mathrm{~km}$ and with time discreteness of 2 hours. For the calculation of turbulent heat and moisture flows based on meteorological parameters obtained from the SKIRON model calculations, the balk-formulas *** are used.

For the purpose of the simulation results do not strongly deviate from observational data, two types of regularization of the model solution are used. The first type is nudging. The implementation of this method consists in adding relaxation terms to the equations for temperature and salinity, representing the difference between the climatic and model values of these characteristics multiplied by the relaxation coefficient, which is equal to the inverse relaxation time of the model to the observations [15]. This method is mainly used for deep layers in the BS models [16]. The method can be considered as a simple assimilation of climate data observations in the ocean models.

The second type is the correction of flows at the sea surface, which is used to ensure that the model does not deviate from the observations in the near-surface layers. Its difference from nudging is that the relaxation terms (similar to those used in nudging) are not added to the equations for temperature and salinity, but only to the heat and salt flows on the sea surface [17]. In this case, the relaxation coefficient with respect to $T$ and $S$ has the velocity dimension. Adding relaxation

\footnotetext{
* Matishov, G. and Levitus, S., eds., 2008. Climatic Atlas of the Sea of Azov. NOAA Atlas NESDIS 65. Washington, D.C.: U.S. Government Printing Office, 148 p. CD-ROM.

** World Ocean Atlas 2013 version 2. Available at: https://www.nodc.noaa.gov/OC5/woa13/ [Accessed: 20 May 2019].

*** Gill, A.E., 1982. Atmosphere-Ocean Dynamics. New York: Academic Press, 662 p.
} 
supplements to heat and fresh water flows is one of the methods for taking into account negative feedbacks present in the joint system of the atmosphere and the ocean, when modeling processes in the ocean separately. Due to the fact that heat flows are calculated with greater accuracy than fresh water ones (precipitation minus evaporation), often only the correction for salinity is used [18].

In the framework of the present work, the draw of surface $S$ salinity to climatic data is carried out by adding to the normalized flow of salt on the sea surface (calculated as the difference in precipitation and evaporation multiplied by the sea surface salinity) of the relaxation supplement. It is the difference in the model and climatic near-surface salinity multiplied by coefficient $\alpha_{S}=10 \mathrm{~m} / 120$ days. The presented $\alpha_{S}$ value is interpreted as relaxation of the simulated $S$ salinity, averaged over a $10 \mathrm{~m}$ upper layer and climate values with 120 day time scale. The need for this correction is also that it (improves) the amount of precipitation, which always contains errors in atmospheric models.

For $T$ temperature, correction is also made to the sea-surface temperature data used in SKIRON atmospheric model, with the same relaxation parameter as in the case of $S$ salinity. It should be noted that a draw with $T$ is optional, since for it there is already a stabilizing negative reaction given by bulk formulas for calculating the turbulent heat flow. However, such correction permits to keep the surface $T$ temperature close to the range of values used in the SKIRON model, and thus harmonize the atmospheric and marine models.

For model $S$ and $T$ values [19, 20], at depths below $150 \mathrm{~m}$, nudging is used for climatic values with $\frac{1}{120}$ day $^{-1}$ relaxation coefficient [8]. Nudging to climatic values at depths below $150 \mathrm{~m}$ is caused by the fact that the BS circulation is characterized by large shallow depths that lead to errors in the approximation of the horizontal components of the pressure gradient in $\sigma$-models. Due to the complex topography, such nudging is used in almost all BS models, regardless of the type of the vertical coordinate (see, for example, [16]).

For the large BS rivers, including the Danube, Dniester, Dnieper, Rioni, Inguri, Yesilirmak, Kyzylyrmak, Sakarya, real climatic discharge data are set *.

The BAMS model is implemented for the water area of three seas at once, therefore the conditions on the liquid boundary are set only in the Dardanelles Strait, where climatic values for temperature and salinity and, consequently, geostrophic velocities (the model reproduces them for a given density) are prescribed. Thus, in the Bosphorus Strait, the currents are calculated according to the spatial resolution and atmospheric forcing. Since three-dimensional mean monthly climatic fields are used to build the initial conditions for temperature and salinity, the numerical calculation starts on December 01, 2010, a month before the basic numerical calculation, which, in turn, is carried out for a period of one year from January, 01, 2011 to December, 31, 2011 with a data release resolution of 6 hours. Such a short duration of the adaptation phase is due to the strong correction to climate data.

* Dzhaoshvili, Sh.V., 2003. Reki Chernogo Morja [The Rivers of the Black Sea]. Technical Report No. 71. European Environment Agency, 186 p. Available at: https://www.eea.europa.eu/ru/publications/technical_report_2002_71/at_download/file [Accessed: 20 May 2019] (in Russian). 
Similar to previous work *, the obtained simulation results are compared with the data of vertical salinity and temperature distributions obtained from ARGO floats drifting in the BS waters in 2011 at a parking depth within 500-1500 m (Table 1).

Table 1

Parameters of the considered ARGO floats drifting in the BS in 2011

\begin{tabular}{c|c|c|c}
\hline ARGO & $\begin{array}{c}\text { Considered operating } \\
\text { Float ID }\end{array}$ & $\begin{array}{c}\text { Parking depth/maximum } \\
\text { profiling depth, db }\end{array}$ & $\begin{array}{c}\text { Number of the } \\
\text { considered profiles }\end{array}$ \\
\hline 7900465 & $02.01 .2011-28.12 .2011$ & 500 & 70 \\
7900466 & $02.01 .2011-28.12 .2011$ & 500 & 65 \\
1901200 & $05.01 .2011-31.12 .2011$ & $700 / 1500$ & 72 \\
6900803 & $19.03 .2011-19.12 .2011$ & $700 / 1500$ & 55 \\
6900804 & $19.03 .2011-29.12 .2011$ & $700 / 1500$ & 58 \\
6900805 & $19.03 .2011-29.12 .2011$ & $700 / 1500$ & 57 \\
\hline
\end{tabular}

\section{Comparative Analysis Results}

For a comparative analysis, all the data of numerical calculations and field measurements are distributed in accordance with certain layers of the Black Sea waters subsurface layer $(0-5 \mathrm{~m})$, upper mixed layer $(5-30 \mathrm{~m})$, cold intermediate layer $(30-100 \mathrm{~m})$, main pycnocline $(100-300 \mathrm{~m})$ and a layer of sub-pycnocline divided into two sublayers: $300-800 \mathrm{~m}$ and $800-1500 \mathrm{~m}$ ). The horizon at $800 \mathrm{~m}$ level of separating the sub-pycnocline is chosen because of the intensification of current velocities found at [21] at a given depth and below $1200 \mathrm{~m}$. The last layer is limited to a depth of $1500 \mathrm{~m}$, since this is the maximum depth of profiling by ARGO floats drifting in the BS in 2011.

To estimate the accuracy of reproducing the salinity and temperature fields with the BAMS model, the mean and rms deviations of the model values of these characteristics from the values measured by ARGO floats are calculated for the selected layers. The procedure for calculating mean and rms is as follows: first of all, for each of the considered floats and its profiling points, the corresponding model profiles are selected. Note that within the framework of this research, the selected profiles are not interpolated to the measurement point, but are taken from the model grid area point nearest to it. Then, for all the selected model and measured profiles of a specific buoy, the mean values of the characteristics ( $S$ and $T$ ) for each of the previously presented layers are found. Further, the corresponding mean values of the model data are subtracted from the obtained mean values of field measurements for each profile and layer, and all the resulting deviations are averaged among the layers. A similar procedure is repeated for all floats. After that, to find the mean value, the layer-average one is taken between the obtained values. The calculation of rms value differs in that in the last stage, it is not a layer-bylayer mean that is calculated, but a layer-by-layer standard deviation.

* Markova, N.V., Dymova, O.A. and Demyshev, S.G., 2019. Numerical Simulations of the Black Sea Hydrophysical Fields below the Main Pycnocline: Validation by ARGO Data. In: V. Karev D. Klimov, K. Pokazeev, eds., 2018. Physical and Mathematical Modeling of Earth and Environment Processes. Springer Proceedings in Earth and Environmental Sciences. Cham: Springer, pp. 15-21. https://doi.org/10.1007/978-3-030-11533-3_2 
The comparative analysis results are given in Tab. 2. It shows that the maximum values of the temperature $\mathrm{rms}$ are found in the subsurface $(0-5 \mathrm{~m})$ and upper mixed $(5-30 \mathrm{~m})$ layers and are $0.6{ }^{\circ} \mathrm{C}$ и $0.44{ }^{\circ} \mathrm{C}$, respectively. For salinity, the maximum value of rms (0.49) refers to the cold intermediate layer (30$100 \mathrm{~m}$ ). Based on the obtained results and the results of earlier experiments [22], it can be assumed that one of the main reasons for achieving rms maximum values in the cold intermediate layer $(30-100 \mathrm{~m})$ and above is the depth shift in the model results of the density jump layer. In the sub-pycnocline layer (300-1500 m), the deviation of the measured values from the model values does not exceed $0.13{ }^{\circ} \mathrm{C}$ and 0.07 for $T$ and $S$, respectively. The mean and rms values decrease with depth, but in the 800-1500 $\mathrm{m}$ layer for temperature, they slightly increase. Apparently, the decrease in values is due to the fact that the temperature variability decreases with depth and the data of ARGO floats are close to the climatic ones. The deviation in the 800-1500 m layer is explained by the fact that here the data of ARGO floats on temperature are very different from the mean monthly climatic data, which at depths below $150 \mathrm{~m}$ the model data is linked to. In addition, this may indicate increased temperature variability in the 800-1500 m layer, leading to the intensification of currents, found in [21].

Consider the nature of the deviations of the simulation results of ARGO float measurements in more detail. For each of the floats (all points of its trajectory), vertical profiles of deviations of the model results for temperature and salinity from the measured ones are built. For this purpose, all data is interpolated to the same depth horizons: 2,$5 ; 5 ; 10 ; 15 ; 20 ; 25 ; 30 ; 40 ; 50 ; 62,5 ; 75 ; 87,5 ; 100 ; 112,5 ; 125$; $150 ; 200 ; 300 ; 400 ; 500 ; 700 ; 900 ; 1100 ; 1300 ; 1500 \mathrm{~m}$. Each of them calculates the difference of the corresponding measured and model values. Fig. 1 shows the average profiles for the calculated deviations from the temperature and salinity data for the 6900804 buoy and selective deep-water profiles of the temperature and salinity deviations. The data used to build the figures is taken for the operation period of the selected buoy (from March 19, 2011 to December 29, 2011). The presented drawings clearly confirm the results previously obtained and listed in Tab. 2.

Table 2

\section{The mean and rms deviations of model $T$ and $S$ from the values measured} with ARGO floats

\begin{tabular}{c|cc|c|c}
\hline \multirow{2}{*}{ Layer depth, $\mathrm{m}$} & \multicolumn{2}{|c|}{ Temperature, ${ }^{\circ} \mathrm{C}$} & \multicolumn{2}{c}{ Salinity, \%o } \\
\cline { 2 - 5 } & mean & rms & mean & rms \\
\hline $0-5$ & -0.450 & 0.602 & -0.095 & 0.160 \\
$5-30$ & 0.223 & 0.436 & -0.145 & 0.149 \\
$30-100$ & -0.218 & 0.292 & 0.402 & 0.487 \\
$100-300$ & 0.072 & 0.080 & 0.180 & 0.202 \\
$300-800$ & 0.051 & 0.052 & -0.059 & 0.067 \\
$800-1500$ & 0.125 & 0.125 & -0.003 & 0.008 \\
\hline
\end{tabular}

From Fig. 1, a it can be seen that in the subsurface layer $(0-5 \mathrm{~m})$, on average, the model overestimates the temperature compared to the ARGO data, in the 5-30 m layer, on the contrary, it underestimates, on average, and in the layer 
30-100 m again overestimates. In the deep-water layers below $800 \mathrm{~m}$, the deviations in temperature slightly increase, which corresponds to the Tab. 2

Deviations in salinity have a simpler structure in depth (Fig. 1, b). In the 0-50 m layer, on average, the model overestimates salinity compared with the ARGO data, while in the layer from 50 to $\sim 300 \mathrm{~m}$, on the contrary, it underestimates. In the deep-water layers below $300 \mathrm{~m}$, there are no significant deviations between the salinity data.

In the subsurface layer, temperature and salinity errors have the same sign. These errors indicate that the SKIRON data on sea surface $T$ temperature and climatic data on $S$ salinity differ from the ARGO data. The nature of the error profiles in depth corresponds to those presented in [16]: the model in the 50-200 m layer rather strongly underestimates the salinity, and in the 50-100 m layer it overstates the temperature.

For a detailed visual presentation of the results obtained for the deep-water layers below the cold intermediate layer (30-100 m), in Fig. 2 shows the deviations of the layer-averaged values of field measurements from the corresponding model data values along the path of movement of the 900804 float for the considered period of its operation. Analyzing the figures presented, it is clearly seen that for the sub-pycnocline layer (300-1500 m), the deviations of the compared data for both characteristics of the marine environment are insignificant. The previously discussed deterioration of the consistency of the compared data in the main pycnocline layer $(100-300 \mathrm{~m})$ is also traced.
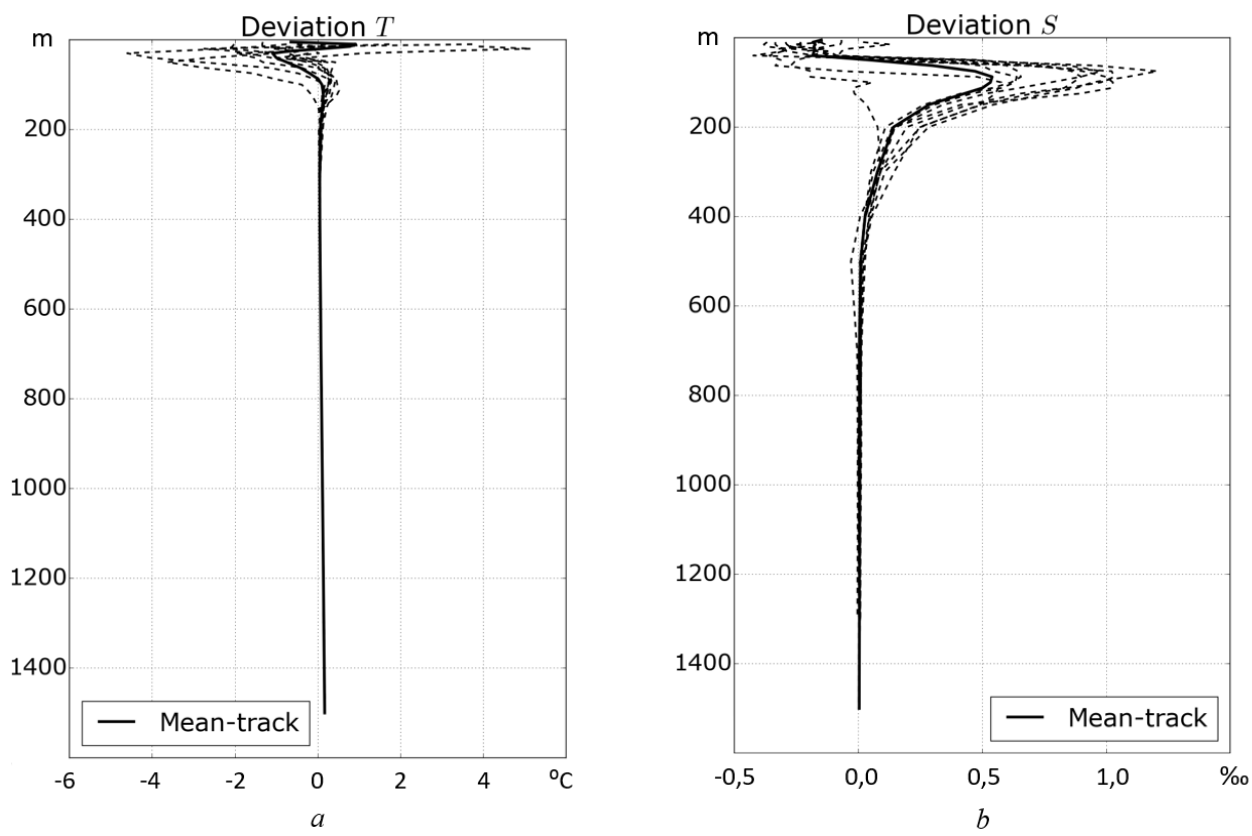

F i g. 1. Vertical mean profile of all the deviations (solid line) and sampling deep-water deviation profiles (dotted lines) along the trajectory of the 6900804 buoy motion: a) temperature $\left({ }^{\circ} \mathrm{C}\right)$; b) salinity (\%o) 

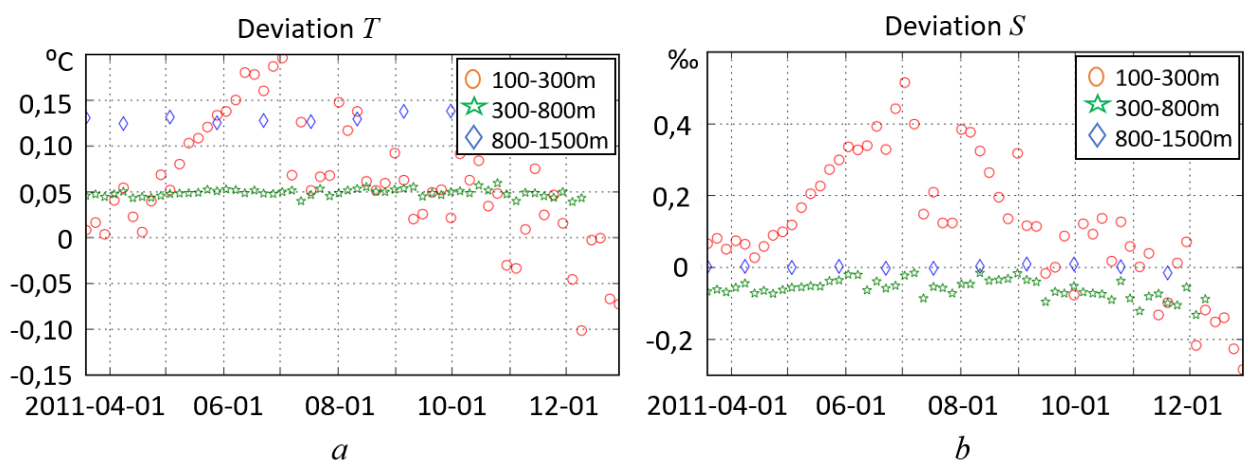

F i g. 2. Values of deviations of the compared data along the trajectory of the 6900804 buoy motion for the main pycnocline $(100-300 \mathrm{~m})$ and the sub-pycnocline $(300-1500 \mathrm{~m}): a$ ) temperature $\left({ }^{\circ} \mathrm{C}\right)$; b) salinity $(\%)$

Due to the fact that the ARGO floats do not measure the current velocities directly, validation of model currents is possible only on the basis of the mean current velocities in the deep-water layers calculated in [21] according to their movement data. In accordance to the layer-by-layer estimates of the mean velocities obtained in this work, it is believed that below the main pycnocline $(100-300 \mathrm{~m})$ they are $\sim 4 \mathrm{~cm} / \mathrm{s}$, and in the layer of $800-1200 \mathrm{~m}$ they increase to $6 \mathrm{~cm} / \mathrm{s}$. If we take into account all the data processed, the highest values of mean velocities are observed in January - March, and the lowest -in June - October [21].

To analyze the velocities of deep-sea currents obtained from the numerical simulation results, the mean August 2011 values of along-coast components of the velocity of deep-water currents are built on cross sections to the coast along the two locations previously selected in the work *: the Bulgarian $\left(28^{\circ} 0^{\prime} \mathrm{E}, 42^{\circ} 0^{\prime} \mathrm{N}\right)$ and the Caucasus $\left(39^{\circ} 12^{\prime} \mathrm{E} ; 43^{\circ} 54^{\prime} \mathrm{N}\right)$ coasts.

Presented in Fig. 3 along-coastal velocity components indicate some features of deep-sea currents that are uncharacteristic of the conventional BS cyclonic water circulation scheme. Here, the positive values of the velocities correspond to the anticyclonic directionality of the currents, and the negative ones - to the cyclonic one. In these figures, the anticyclonic circulation is clearly visible at depths of $800 \mathrm{~m}$ with current velocities reaching $1.5 \mathrm{~cm} / \mathrm{s}$. The depth of the anticyclonic circulation is somewhat lower than the previously mentioned layer-by-layer estimates of mean velocities below the main pycnocline $(100-300 \mathrm{~m})$ [21]. This may be a consequence of previously detected temperature deviations of the model and measured values in the 800-1500 m layer.

Due to the detected deviation in the 800-1500 m layer in temperature, further attention should be paid to the model parameters associated with the correction of model depth data and the quality of the data used for it.

* Markova, N.V., Dymova, O.A. and Demyshev, S.G., 2019. Numerical Simulations of the Black Sea Hydrophysical Fields below the Main Pycnocline: Validation by ARGO Data. In: V. Karev D. Klimov, K. Pokazeev, eds., 2018. Physical and Mathematical Modeling of Earth and Environment Processes. Springer Proceedings in Earth and Environmental Sciences. Cham: Springer, pp. 15-21. https://doi.org/10.1007/978-3-030-11533-3_2 

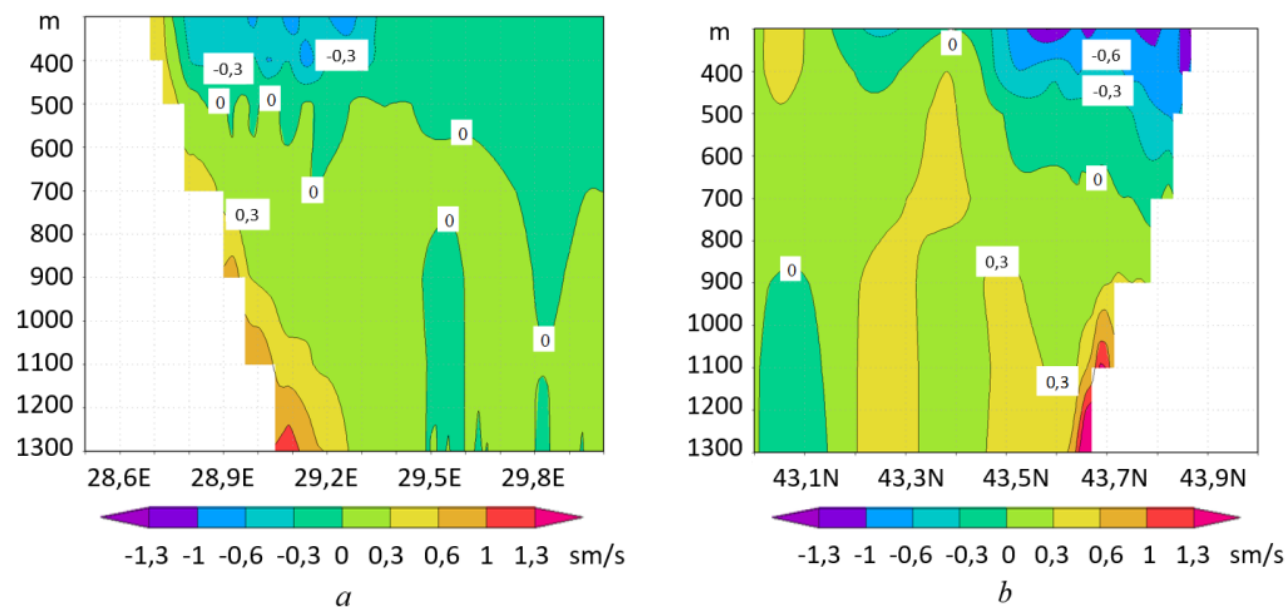

F i g. 3. August-average values of the along-coastal currents' velocity components at the sections normal to the coast: $a$ ) meridian velocity component near the Bulgarian coast; $b$ ) zonal velocity component near the Caucasian coast

\section{Conclusion}

The present paper gives the analysis of the results of comparing the Black Sea salinity and temperature fields, calculated using the INMOM marine circulation model for BAMS waters and measured by ARGO floats in 2011. It was found that the largest deviations of the considered characteristics of the marine environment belong to the upper sea layers $(0-100 \mathrm{~m})$. It is also shown that in the deep-water layers $(300-1500 \mathrm{~m})$ the consistency level between the simulation results and the field data is much higher. However, when comparing the data, large deviations were observed between the compared temperature data in the lower layer of the sub-pycnocline $(800-1500 \mathrm{~m})$. The main reason for the identified deviations for both characteristics in the upper sea layers and for the temperature in the lower layer of the sub-pycnocline can be associated with data that is assimilated using correction on surface and nudging in depth.

Analysis of model currents was carried out. It showed some features of deepsea currents that are not typical of the generally accepted cyclonic circulation scheme of the considered marine area. Anticyclonic circulation was detected at depths below $800 \mathrm{~m}$ with current velocities reaching $1.5 \mathrm{~cm} / \mathrm{s}$. The intensity of the deep-water longshore anticyclonic circulation in the presented calculations turned out to be lower than in [21].

Generally, the calculations presented show that it is not yet possible confidently judge on the deep-sea anticyclonic circulation structure. The reason is that there are many uncertainties in the initial observational data and reproduction of the BS deep circulation is difficult because of the features of the BS bottom topography, characterized by large continental slopes. To clarify the nature of the BS deep circulation, it is necessary to carry out further field and model studies. 


\section{REFERENCES}

1. Demyshev, S.G., Dymova, O.A., Markova, N.V. and Piotukh, V.B., 2016. Numerical Experiments on Modeling of the Black Sea Deep Currents. Physical Oceanography, [e-journal] (2), pp. 34-45. doi:10.22449/1573-160X-2016-2-34-45

2. Pavlushin, A.A., Shapiro, N.B. and Mikhailova, E.N., 2017. The Role of the Bottom Relief and the $\beta$-Effect in the Black Sea Dynamics. Physical Oceanography, [e-journal] (6), pp. 2435. doi: 10.22449/1573-160X-2017-6-24-35

3. Stanev, E.V., 1990. On the Mechanisms of the Black Sea Circulation. Earth-Science Reviews, [e-journal] 28(4), pp. 285-319. https://doi.org/10.1016/0012-8252(90)90052-W

4. Bulgakov, S.N., Korotaev, G.K. and Whitehead, J.A., 1996. The Role of Buoyancy Fluxes in the Formation of a Large-Scale Circulation and Stratification of Sea Water: 2. Laboratory Experiments. Izvestiya, Atmospheric and Oceanic Physics, 32(4), pp. 514-520.

5. Sarkisyan, A.S. and Dzhioev, T.Z., 1974. Diagnosticheskaya Model' i Raschet Techeniy v Chernom More [A Numerical Model and Calculation of Currents in the Black Sea]. Meteorologiya i Gidrologiya, (3), pp. 70-76 (in Russian).

6. Marchuk, G.I., Kordzadze, A.A. and Skiba, Yu.N., 1975. Calculation of the Basic Hydrological Fields in the Black Sea. Izvestiya of Academy of Sciences, USSR. Atmospheric and Oceanic Physics, 11(4), pp. 229-237.

7. Petrenko, L.A. and Kushnir, V.M., 2006. Klimaticheskie Pridonnye Techenija v Chernom More [Climatic Bottom Currents in the Black Sea]. In: MHI, 2006. Ekologicheskaya Bezopasnost' Pribrezhnoy i Shel'fovoy Zon i Kompleksnoe Ispol'zovanie Resursov Shel'fa [Ecological Safety of Coastal and Shelf Zones and Complex Use of Shelf Resources]. Sevastopol: MHI NANU. Iss. 14, pp. 477-486 (in Russian).

8. Diansky, N.A., Fomin, V.V., Zhokhova, N.V. and Korshenko, A.N., 2013. Simulations of Currents and Pollution Transport in the Coastal Waters of Big Sochi. Izvestiya, Atmospheric and Oceanic Physics, [e-journal] 49(6), pp. 611-621. https://doi.org/10.1134/S0001433813060042

9. Marchuk, G.I., Rusakov, A.S., Zalesny, V.B. and Diansky, N.A., 2005. Splitting Numerical Technique with Application to the High Resolution Simulation of the Indian Ocean Circulation. Pure and Applied Geophysics, [e-journal] 162(8-9), pp. 1407-1429. https://doi.org/10.1007/s00024-005-2677-8

10. Griffies, S.M., Böning, C., Bryan, F.O., Chassignet, E.P., Gerdes, R., Hasumi, H., Hirst, A., Treguier, A.-M. and Webb, D., 2000. Developments in Ocean Climate Modelling. Ocean Modelling, [e-journal] 2(3-4), pp. 123-192. https://doi.org/10.1016/S1463-5003(00)00014-7

11. Brydon, D., Sun, S. and Bleck, R., 1999. A New Approximation of the Equation of State for Seawater, Suitable for Numerical Ocean Models. Journal of Geophysical Research: Oceans, [e-journal] 104(C1), pp. 1537-1540. https://doi.org/10.1029/1998JC900059

12. Zalesny, V., Diansky, N., Fomin, V., Moshonkin, S.N. and Demyshev, S.G., 2012. Numerical Model of the Circulation of the Black Sea and the Sea of Azov. Russian Journal of Numerical Analysis and Mathematical Modelling, [e-journal] 27(1), pp. 95-112. doi:10.1515/rnam-2012-0006

13. Polonsky, A.B., Shokurova, I.G. and Belokopytov, V.N., 2013. Desjatiletnjaja Izmenchivost' Temperatury i Solenosti v Chernom More [Decadal Variability of Temperature and Salinity in the Black Sea]. Morskoy Gidrofizicheckiy Zhurnal, (6), pp. 27-41 (in Russian).

14. Pacanowski, R.C. and Philander, S.G.H., 1981. Parametrization of Vertical Mixing in Numerical Models of Tropical Oceans. Journal of Physical Oceanography, [e-journal] 11(11), pp. 1443-1451. https://doi.org/10.1175/1520-0485(1981)011<1443:POVMIN>2.0.CO;2

15. Otte, T.L., Nolte, C.G., Otte, M.J. and Bowden, J.H., 2012. Does Nudging Squelch the Extremes in Regional Climate Modeling? Journal of Climate, [e-journal] 25(20), pp. 7046-7066. https://doi.org/10.1175/JCLI-D-12-00048.1

16. Dorofeyev, V.L. and Sukhikh, L.I., 2017. Modeling of Long-Term Evolution of Hydrophysical Fields of the Black Sea. Oceanology, [e-journal] 57(6), pp. 784-796. https://doi.org/10.1134/S0001437017060017

17. Diansky, N.A., Bagno, A.V. and Zalesny, V.B., 2002. Sigma Model of Global Ocean Circulation and Its Sensitivity to Variations in Wind Stress. Izvestiya, Atmospheric and Oceanic Physics, 38(4), pp. 477-494. 
18. Danabasoglu, G., Yeager, S.G., Bailey, D., Behrens, E., Bentsen, M., Bi, D., Biastoch, A., Böning, C. and Bozec, A. [et al.], 2014. North Atlantic Simulations in Coordinated Ocean-Ice Reference Experiments Phase II (CORE-II). Part I: Mean States. Ocean Modelling, [e-journal] 73, pp. 76-107. doi:10.1016/j.ocemod.2013.10.005

19. Dianskiy, N.A., Fomin, V.V., Chumakov, M.M. and Stepanov, D.V., 2017. Application of Modern Numerical Ocean and Ice Models for Retrospective Simulations of Circulation and Ice Cover of Okhotsk Sea. In: M. N. Mansurov and D. A. Onishchenko, eds., 2017. Vesti Gazovoy Nauki. Gazprom VNIIGAZ LLC. Iss. 4(32), pp. 82-93 (in Russian).

20. Lorenc, A.C., Bell, R.S. and Macpherson, B., 1991. The Meteorological Office Analysis Correction Data Assimilation Scheme. Quarterly Journal of the Royal Meteorological Society, [e-journal] 117(497), pp. 59-89. https://doi.org/10.1002/qj.49711749704

21. Markova, N.V. and Bagaev, A.V., 2016. The Black Sea Deep Current Velocities Estimated from the Data of Argo Profiling Floats. Physical Oceanography, (3), pp. 23-35. doi:10.22449/1573-160X-2016-3-23-35

22. Korotaev, G.K., Oguz, T., Dorofeyev, V.L., Demyshev, S.G., Kubryakov, A.I. and Ratner, Yu.B., 2011. Development of Black Sea Nowcasting and Forecasting System. Ocean Science, [e-journal] 7(5), pp. 629-649. doi:10.5194/os-7-629-2011

About authors:

Evgeniya A. Korshenko - Junior Research Associate, N. N. Zubov State Oceanographic Institute (6, Kropotkinskiy Ave., Moscow, 119034, Russian Federation), ORCID ID: 0000-00032310-9730, zhenyakorshenko@ gmail.com

Nikolay A. Diansky - Chief Research Associate, Lomonosov Moscow State University (build. 2, GSP-1, Leninskie Gory, Moscow, 119991, Russian Federation), Dr. Sci. (Phys.-Math.), Senior Lecturer, ORCID ID: 0000- 0002-6785-1956, ResearcherID: R-8307-2018, nikolay.diansky@gmail.com

Vladimir V. Fomin - Senior Research Associate, N. N. Zubov State Oceanographic Institute (6, Kropotkinskiy Ave., Moscow, 119034, Russian Federation), ORCID ID: 0000-0001- 8857-1518, ResearcherID: C-2124-2017, vladimirfomin@gmail.com

Contribution of the co-authors:

Evgeniya A. Korshenko - data preparation, carrying out numerical experiments using the Black Sea circulation model; analysis and validation of the research results; preparation of graphic materials and the text preparation

Nikolay A. Diansky - formulation of the research problem; scientific supervision of the paper; consulting support; discussion of the work results; critical analysis and revision of the text

Vladimir V. Fomin - assistance in carrying out numerical experiments; analysis and synthesis of the research results; discussion of the work results; editing and supplementation of the article text

All the authors have read and approved the final manuscript.

The authors declare that they have no conflict of interest. 